ISSN 1230-929 X

http://dx.doi.org/10.12775/ED.2021.009

\title{
RECENZJE
}

\author{
Ewa Skibińska
}

ORCID 0000-0002-5325-6507

\section{EWA DĘBSKA: PROFILE REFLEKSYJNOŚCI I TYPY KARIER. PERSPEKTYWA PORADOZNAWCZA. WYDAWNICTWO UNIWERSYTETU WARSZAWSKIEGO, WARSZAWA 2020, s. 370}

W ostatnich dziesięcioleciach w naukowych publikacjach pedagogicznych w Polsce zauważyć można wzrastające zainteresowanie problematyką nieobecną lub traktowaną marginalnie jeszcze w latach 80 . XX wieku. Mam tutaj na uwadze (w kontekście recenzowanej książki) zagadnienia związane z karierą (w tym zawodową) oraz refleksją/ refleksyjnością. Nigdy dotychczas badacze i teoretycy nie łączyli tej tematyki ze sobą $i$, co więcej, nie przedstawiali w teoretycznej perspektywie poradoznawczej. Takie podejście proponuje w swojej pracy monograficznej pt. Profile refleksyjności i typy karier. Perspektywa poradoznawcza jej autorka - Ewa Dębska. Przedstawia zatem nowe ujęcie powyższej problematyki, które w konsekwencji decyduje o oryginalności pracy zarówno w wymiarze badawczym, jak i teoretycznym.

W monografii Ewa Dębska przede wszystkim prezentuje wyniki przeprowadzonych przez siebie badań z udziałem doradców zawodu. Jak pisze autorka, podjęła w niej próbę [...] odkrycia sposobów poddawania refleksji przebiegu kariery przez doradców zawodu, którzy profesjonalnie zajmuja się wspieraniem innych w konstruowaniu biografii edukacyjno-zawodowej (s. 20). Projektując własne badania, analizując zgromadzony materiał badawczy oraz prezentując wynikające z tej analizy wnioski Ewa Dębska odwołuje się do szeregu koncepcji, teorii i badań przeprowadzonych wcześniej przez różnych uczonych (w kraju i za granicą), tworząc w ten sposób rozległy kontekst teoretyczny dla własnych przemyśleń.

Swoje rozważania autorka rozpoczyna od syntetycznego przedstawienia rozumienia pojęć refleksji i refleksyjności w literaturze naukowej (w rozdziale 1: $O$ różnych ujęciach refleksyjności i refleksji). Swoistym wstępem do usytuowania 
tych pojęć w przestrzeni naukowej jest pokazanie ich w ujęciu semantyki. Dalej autorka opisuje związek i rolę refleksji w biegu życia człowieka dorosłego (od okresu wczesnej, przez średnią, do późnej dorosłości). Przywołuje wybrane teorie dotyczące funkcjonowania człowieka starszego, które akcentują znaczenie refleksyjności w ich rozwoju, podkreśla procesualny i rozwojowy charakter refleksyjności w tym etapie życia. Wiele uwagi autorka poświęca refleksyjności w kontekście stylu poznawczego człowieka, pokazuje jej związek z przebiegiem procesu uczenia się i jego efektami, odwołując się przy tym do wielu badań i eksperymentów psychologicznych. Przeciwstawia poznawcze funkcjonowanie osób charakteryzujących się stylem refleksyjnym uczenia się osobom o impulsywnym stylu uczenia się. Pokazuje nie tylko atuty refleksyjnego stylu poznawczego, ale także jego ułomności ujawniające się w pewnych sytuacjach edukacyjnych. Interesujące są przemyślenia Ewy Dębskiej na temat bezrefleksyjności i jej skutków w procesie uczenia się. Refleksja jest przez autorkę przedstawiona także jako szczególna kompetencja, opisywana głównie w publikacjach poświęconych praktyce zawodowej (profesjonalizacji pracy). Zamykając kwestię rozumienia pojęć refleksja i refleksyjność, autorka wskazuje na ich rozróżnianie w literaturze (pokazuje podobieństwa i różnice), ale także na ich zamienne stosowanie.

Najwięcej miejsca w rozważaniach na kanwie literatury naukowej autorka poświęca miejscu refleksji i refleksyjności w poradoznawstwie (w rozdziale 2: $O$ refleksji i refleksyjności we wspótczesnym poradoznawstwie). Nie jest możliwe przedstawienie całej podjętej w tym obszarze problematyki, a jedynie jej zasygnalizowanie. Pierwszą kwestią szczegółową podjętą przez autorkę jest poradnictwo całożyciowe (m.in. jego cele w świetle dokumentów UE, jego zadania realizowane w Polsce, zadania doradców w świetle przeprowadzonych badań i ich kompetencje). Ewa Dębska przedstawia też krytyczne opinie na temat poradnictwa całożyciowego, które - zdaniem krytyków - kształtuje bezrefleksyjną i przystosowawczą postawę klienta, wskazuje drogi do zatrudnienia, a nie do rozwoju. Autorka konstatuje, że w poradnictwie całożyciowym jest miejsce na refleksyjność zarówno klienta, jak i doradcy. Swoje stanowisko starannie oraz przekonująco uzasadnia.

Ewa Dębska wybiera podejście strukturalistyczne dla scharakteryzowania problemu władzy stosowanej w poradnictwie. Problem ten pokazuje w ujęciu systemowym i indywidualnym. W ujęciu systemowym autorka podejmuje krytyczną refleksję nad pracą doradcy. Wyjaśnia, w jaki sposób system ogranicza wolność doradcy w aspektach: miejsca, czasu i narzędzi pracy, oraz kontroli klientów. Pokazuje też relacje doradcy z klientem jako możliwość obszaru ochrony własnej wolności przez doradcę. W ujęciu indywidualnym uznaje, że władza doradcy nad klientem wynika $\mathrm{z}$ tworzenia przez niego iluzji wolności i wolnych wyborów, z posiadania dóbr, wiedzy o kliencie, sposobu prowadzenia rozmowy doradczej. Uzasadnia to szczególną rolę refleksji (namysłu nad własnym postępowaniem) w podejmowaniu lub nie - działania przez doradcę. Autorka dostrzega konieczność 
niezależności doradcy w poznawczym, emocjonalnym i praktycznym działaniu, aby nie był narzędziem w ręce władzy.

Ewa Dębska pokazuje możliwości wykorzystania przez doradców podejścia konstruktywistycznego w poradnictwie kariery. Zasadza się ono na wykorzystaniu przez doradców, towarzyszących klientowi w refleksyjnym konstruowaniu własnej biografii, założeń konstruktywizmu. Przejawiałoby się to w wykorzystaniu narracji (dla konstruowania i rekonstruowania kariery) narzędzi projekcyjnych, w uwzględnianiu społeczno-kulturowego kontekstu. Doradcę spostrzega autorka jako refleksyjnego praktyka i refleksyjnego badacza swojej praktyki zawodowej. Przywołuje koncepcję Life Design dotyczącą konstruowania drogi zawodowej i poradnictwa kariery, proponującą holistyczne podejście całożyciowe łączące aktywność zawodową, edukacyjną z innymi sferami życia. Tłumaczy, na czym polega refleksyjność doradcy i refleksyjność klienta w tej koncepcji. Refleksyjność w poradnictwie zorientowanym konstruktywistycznie autorka wyjaśnia także na przykładzie dwóch koncepcji autorskich: Marka Savickasa i Jeana Guicharda. Refleksyjność w orientacji konstruktywistycznej w odniesieniu do poradnictwa autorka sytuuje w obrębie rozmowy doradczej prowadzonej dialogowo.

Wiele uwagi Ewa Dębska poświęca karierze (w rozdziale 3: Kariera i różne jej odsłony). Uważa, że kariera jest [...] wieloznaczeniowa, wielowarstwowa i ulokowana w różnych kontekstach funkcjonowania jednostki (s. 127), co udaje jej się udowodnić. Prezentuje wybrane modele kariery, jej wzory i typy opisywane w literaturze przedmiotu. Przedstawia dwie typologie karier: homogeniczne (łączące tradycyjne, biurokratyczne podejścia, gdy kariera jest realizowana zgodnie z wyznaczonym układem stanowisk w organizacji) oraz heterogeniczne (związane ze zmianami form organizacji pracy, podkreślające subiektywny wymiar kariery). Interesujący jest opisany przez autorkę tzw. proteuszowy model kariery.

Nawet tak pobieżny przegląd podejmowanych przez autorkę kwestii pokazuje, jak różnorodną podstawę teoretyczną przyjęła dla swoich badań, z jaką swobodą porusza się $w$ tematyce wielu dyscyplin naukowych. Nie unika przy tym dzielenia się z czytelnikiem swoimi przemyśleniami oraz przedstawiania swojego stanowiska w kwestiach czasem budzących kontrowersje.

Ewa Dębska w swoich badaniach wykorzystuje strategię jakościową, a dokładniej założenia konstruktywizmu. Wybór takiego podejścia dokładnie i przekonująco wyjaśnia w tekście (w rozdziale 4: Założenia metodologiczne badań nad refleksyjnościa doradców zawodowych w konstruowaniu swojej kariery). Poszukuje przede wszystkim odpowiedzi na pytanie: $W$ jaki sposób doradcy wykorzystuja refleksyjność do konstruowania swojej kariery? (s. 169). W centrum zainteresowań znajduje się osoba doradcy, która przez autorkę jest postrzegana jako [...] jednostka refleksyjna interpretujacca sytuacje, zdarzenia, która nie jest biernym uczestnikiem zachodzacych procesów społecznych, ale która aktywnie działa $i$ wspóttworzy świat spoleczny, konstruuje sama siebie i swoje życie zawodowe (s. 169). Przedmiotem badań autorka czyni zatem refleksyjność doradców zawodowych, którą 
poznaje podczas narracji badanych, kiedy rekonstruują przebieg swojej kariery zawodowej. W tym celu stosuje procedurę indywidualnych bezpośrednich wywiadów mało kierowanych (inaczej swobodnych, nieustrukturyzowanych). Wnikliwie analizuje zgromadzony tą drogą materiał badawczy, w konstruowaniu wniosków proponując nowe podejścia.

Na podstawie wielokrotnych, wnikliwych analiz materiału badawczego Ewa Dębska proponuje różne typologie (w rozdziale 5: Refleksyjność w karierach badanych doradców), które dotyczą zjawisk wcześniej typologizowanych (jak kariery) lub po raz pierwszy poddawanych typologizacji (jak refleksyjność doradców). W każdym z tych przypadków autorka przedstawia nowe, autorskie kryteria podziału. Punktem wyjścia do tworzenia typologii są historie życia opowiedziane przez 23 badanych doradców, scharakteryzowane przez autorkę. Charakterystyki uwzględniają przebieg drogi edukacyjnej i drogi zawodowej doradców, obejmują zatem ich doświadczenia edukacyjne i zawodowe, ale w określonych kontekstach społeczno-kulturowych. Dotyczą różnych obszarów życia uczestników badania. Każdy opis poprzedza cytat $\mathrm{z}$ wypowiedzi osoby badanej, będący kwintesencją jej narracji.

Obiektywne kryteria nie są podstawą opracowanej przez Ewę Dębską typologii karier doradców, ale [...] subiektywnie nadawane przez narratora znaczenia (s. 262) pewnym aspektom życia (m.in. sukcesom i porażkom, konsekwencjom decyzji, kompetencjom, wartościom). Autorka wyróżnia [...] mobilność fizyczna i psychologiczna w obszarze jednego lub wielu pól zawodowych, powiązanych lub niepowiazanych ze soba, lub stabilizacje w obrębie jednej przestrzeni zawodowej, zakres poruszania kwestii związanych ze sfera edukacyjna i ze sfera zawodowa oraz watek szczególnie podkreślany przez doradcę. Stały się one podstawą opracowania pięciu typów karier badanych: kumulatywnej, zrównoważonej, urynkowionej, adaptacyjnej i familijnej. W charakterystyce każdego z tych typów autorka wskazuje aspekty podkreślane przez doradców, które decydują o przypisaniu danej kariery do określonego typu.

Następnym krokiem zbliżającym autorkę do opracowania profili refleksyjności było przyjęcie komponentów tych profili, przede wszystkim treści (czyli wyodrębnienia sfer życia, jakiego profil dotyczył, aspektów narracji, sposobu konstruowania kariery, samowiedzy, celów życiowych, planów na przyszłość, źródeł wiedzy, tematu wyróżniającego narrację), a także refleksji (jej rodzaju i czasu) oraz sposobu narracji (syntaktycznej i semantycznej). Układ tych komponentów decydował o wystąpieniu określonego profilu refleksyjności doradcy: egzystencjalnego, intrapersonalnego, antycypacyjnego, racjonalnego, interpersonalnego. Profile zostały starannie scharakteryzowane z przywołaniem fragmentów narracji badanych, które istotnie wzbogacają te charakterystyki.

Ewa Dębska dokonuje powiązania między przebiegiem karier a refleksyjnością badanego doradcy. Podejmuje udaną próbę odpowiedzi na pytanie: jakie znaczenie ma profil refleksyjności dla przebiegu karier edukacyjnych i zawodowych 
uczestników badania? Autorka przyjęła założenie, że kariera i refleksyjność są przestrzeniami funkcjonowania człowieka uzupełniającymi się [...] w sferze mentalnej i realnie podejmowanych decyzji, działań i ich konsekwencji (s. 310). Pokazała, jak przejawiają się profile refleksyjności w określonych typach karier.

W rozdziale Podsumowanie wyników badań oraz propozycje kolejnych eksploracji Ewa Dębska powraca do koncepcji Savickasa zauważając, że uczestnicy badań pełnią role wykraczające poza jego propozycje. Proponuje zatem wprowadzić jeszcze dwie nowe role: Architekta (własnego życia) oraz Autorytetu wsobnego. Przekonująco i szczegółowo merytorycznie uzasadnia swój pomysł.

Wnioski wyprowadzone przez Ewę Dębską mają charakter teoretyczny oraz wymiar praktyczny. Autorka formułuje szereg propozycji badawczych istotnie uzupełniających i rozszerzających przeprowadzone przez nią badania: zbadanie większej liczby osób, uwzględnienie innego kontekstu kulturowego, badania dynamiczne, w innych przestrzeniach społecznych, analizę refleksji badanego i badacza, refleksyjność osób starszych oraz pracujących w innych zawodach. Zaproponowane przez nią działania praktyczne oscylują wokół edukacyjnego wsparcia dla kształtowania refleksyjności. Autorka uznaje badania nad refleksyjnością jako zasadne. Pisze: Myślę, że warto podejmować badania nad refleksyjnościa, gdyż rozwijaja one wszystkie zainteresowane osoby: w przypadku naukowego dociekania - badacza, a w przypadku potocznego, ale krytycznego ogladu swojego życiaosoby biorace udziat w tym wspólnym przedsięwzięciu. Inspiruja one i prowokuja do indywidualnego procesu myślenia, dzięki któremu jednostka konstruuje siebie jako czlowieka (s. 319).

W monografii autorstwa Ewy Dębskiej każdy czytelnik odnajdzie treści, które być może zainspirują go do refleksji nad własną karierą, będą wsparciem w jej rozwoju lub pomogą wspierać rozwój innych, albo też wskażą nowe obszary badawcze.

Dane do korespondencji:

Dr hab. Ewa Skibińska

emskibin@uw.edu.pl 